\title{
Multi-level governance in quality assurance in Spain: the case of the National Agency for Quality Assessment and Accreditation
}

\section{(ANECA)}

\section{Ana García-Juanatey ${ }^{1}$, Jacint Jordana ${ }^{2}$, David Sancho ${ }^{3}$}

${ }^{1}$ Institut Barcelona d'Estudis Internacionals, Spain; Department of Law, Universitat Pompeu Fabra, Spain, ${ }^{2}$ Institut Barcelona d'Estudis Internacionals, Spain; Department of Political Science, Universitat Pompeu Fabra, Spain, ${ }^{3}$ Department of Political Science, Universitat Pompeu Fabra, Spain.

\begin{abstract}
This paper aims to examine the case of quality assurance in Spain, disentangling the evolution of the National Agency for Quality Assessment and Accreditation (ANECA), that made its way towards consolidation in a context characterized by deep policy transformations and by multiple actors involved. The case of ANECA and the Spanish context is particularly interesting because of the previous existence of several regional agencies before ANECA was created. These multilevel dynamics in quality assurance evolved over the years towards significant levels of coordination, but were not exempt of multiple conflicts. This case may contribute to assessing a gap in the literature: clarifying the role of quality agencies in implementing contested policy changes originated at the European level, identifying at the same time the complexities of multi-level governance.
\end{abstract}

Keywords: multi-level governance, higher education, quality assurance, Spain, ANECA. 


\section{Introduction}

During the last two decades, there has been a radical transformation of higher education policies in Europe. The attainment of the objective of creating a European Higher Education Area (EHEA) set by education ministries in 1999 has promoted changes of higher education configurations of European countries, modifying the structure, practices and cultures of their university systems. The new policy paradigm for the governance of Higher Education Institutions (HEIs) - that was related to the transformative process focusing on European-wide harmonization — was characterized by a strong emphasis on quality assurance mechanisms, as well as incentive-based instruments (Olsen 2007; Dobbins \& Knill 2014).

As a consequence, a new mode of governance for HEIs has emerged, both in regard to policy instruments and institutions. On the one hand, assessments of programs and institutions are now at the forefront of the policy, and standards aimed to define quality of teaching delivery, research activity and other activities performed by HEI are negotiated and implemented across all European countries (Blackmur 2007). In this sense, the governance of this policy field has largely moved, in many cases, from a command-andcontrol logic — often with the strong involvement of hierarchical academic communities - to a logic based on the principles of modern regulatory governance, where nudges, incentives and benchmarking inspire most policy instruments (Musselin 2014; Stensaker et al. 2011). On the other hand, the establishment of quality assurance agencies (QAAs) has also been crucial to this policy change, emerging as the most relevant actors to implement new policies, and working as "transmission belts" of relevant knowledge, particularly regarding new methodologies for quality assessment (Westerheijden 2007; King 2009).

In this paper, we examine Spain as a relevant case of these substantial policy changes, characterized by a strong multi-level character and an intense process of agencification in the field. In Spain, decentralization of higher education to the regions occurred during the 1980s, after the transition to democracy in late 1970s. This distribution came out as a consequence of the establishment of autonomous communities in Spain, when most education policies were devolved to the regions. It was within this context during the nineties that some Spanish regions decided to create quality assessment agencies to support universities, producing experimental policies aimed to improve university practices. The national agency, the ANECA, arrived later, in 2002, when leading regions had already established their quality agencies - in some cases these had already gained relevant expertise and international reputation in the field during the previous years.

Therefore, this paper focuses on analyzing the case of the National Agency for Quality Assessment and Accreditation (ANECA). The case of this agency is particularly relevant for studying multi-level policy dynamics, as it was established in 2002 in a moment when 
various autonomous agencies were already in place. Moreover, this agency went through a process of consolidation amidst a context of open conflict with universities, particularly after 2007, when quality assurance processes became compulsory. Therefore, we think that that disentangling the evolution of this agency would help us to assess the transformation of governance in the field of higher education in Spain: What strategies were put in practice by this agency to achieve its policy goals in such a conflicting arena? How has the relationship between this agency and the rest of the relevant actors involved (such as regional agencies and universities) evolved during this period? What impact did the European framework have on the process?

This paper tries to answer these questions with a preliminary analysis of press, academic literature and legal sources. Additionally, four interviews with relevant informants were conducted, both from national and regional level agencies, as well as universities. Insight from these interviews is also included.

\section{The Europeanization of HEIs: the role of quality assurance agencies}

After some initial steps, in 1999, the Bologna Declaration became a turning point regarding program harmonization and regulation of quality in the field of higher education in Europe. In order to achieve this, in this Declaration the European Ministers of Education set the objective of establishing the European Higher Education Area (EHEA) by 2010 and foresaw the creation of a common assessment framework, based on a European network for quality assurance. On the one hand, accreditation procedures were provided by the European Association for Quality Assurance in Higher Education (ENQA), an association of agencies created in 2003 that promotes European co-operation in this field and disseminates good practices and other information-based resources. On the other hand, an understanding emerged that the implementation of this instrument, "accreditation as a guarantee of quality", should be performed by autonomous quality assurance agencies (QAAs), formally separated from governments and universities.

As a result of this policy process, independent or semi-independent QAAs have proliferated in Europe at various levels of government, becoming central actors of regulatory frameworks. In the case of Europe, the rapid implementation of Bologna-associated reforms, in particular since 2005, required a relatively quick harmonization of quality assessment regulation and practices introduced by the new quality assurance agencies. This policy acceleration in the late 2000s altered the traditional higher education governance systems in most European states, triggering at times considerable resistance to change, particularly by professional communities in universities. In this sense, as accreditation of university degrees became progressively compulsory, agencies were rapidly placed at the 
forefront of the new system of HE governance, as those in charge of introducing the key ingredient in the new mode of governance.

The relevant but scarce literature on the governance of HEIs' quality assurance has paid considerable attention to the strengths and weaknesses of the variety of regulatory instruments used for assuring academic quality (Dill \& Beerkens 2012), but it has paid less attention to the issue of how ministries and intermediary bodies (such as agencies) make decisions and develop their activities and interact on a daily basis with actors inside the sector, to make progress in move forward the implementation of new instruments according to their policy goals (Ferlie et al. 2008). Thus, this paper is also aimed at examining the level of conflict that emerged from the introduction of this new mode of governance within this policy area in Spain, and the role of the national agency in such a policy process. As we will examine, this conflict came from two sides: the universities, that showed resistance to the new policies, and from regional agencies, who saw the arrival of the new agencies as a threat to their competence.

\section{Analysis: an overview about HEI policy in Spain}

In Spain, the focus of external quality assurance are ex-ante and ex-post program evaluation and institutional evaluations. This quality assurance activity is performed jointly by the ANECA and 11 regional agencies ${ }^{1}$, eight of which are full members of the ENQA, the umbrella organization that represents quality assurance organizations from the 48 countries that are members of the EHEA. These agencies are responsible for the quality assurance of higher education institutions, both private and public, present in their territory. In the regions without an agency, or an agency that is not a member of ENQA, the agency responsible for accreditation is the ANECA.

Hereafter, the evolution of this agency is explained in three main stages: the establishment of ANECA and the context in the early stage of the policy (1992-2003); ANECA's development and adaptation in a context of rapid policy change (2004-2010); and adjustments and revisions towards the agency consolidation (2011-2018).

\footnotetext{
${ }^{1}$ The regional agencies that are part of ENQA are the following: AAC-DEVA: Andalusian Agency of Knowledge, Department of Evaluation and Accreditation; ACPUA: Aragon Agency for Quality Assurance and Strategic Foresight in Higher Education; ACSUCYL: The Quality Assurance Agency for the University System in Castilla y León; ACSUG: Agency for Quality Assurance in the Galician University System; AQU-Catalunya: Catalan University Quality Assurance Agency; FM+D: Fundación para el Conocimiento Madrid + D; UNIBASQ: Agency for Quality of the Basque University System. The remaining three agencies, which are not yet fully registered in ENQA, are the following: AQUIB: Agència de Qualitat Universitària de les Isles Balears; ACCUEE: Agencia Canaria de Calidad Universitaria y Evaluación Educativa; AVAP: Agència Valenciana d'Avaluació i Prospectiva.
} 


\subsection{The establishment of ANECA and the context in the early stage of the policy (1992-} 2003)

After the Declaration of the "Bologna framework", in 2001, the Spanish Universities Act (Ley Orgánica 6/2001 de Universidades, LOU) included the creation of an independent external body for quality assurance in higher education (in art. 32). Following this law, ANECA was formally established as a State public sector foundation (trust) by Ministerial Council agreement in July 19, 2002. At that moment, some autonomous quality assurance agencies were already created, such as the case of the Catalan, the Andalusian and the Galician agency. Therefore, the creation of ANECA introduced tension in the system, as regional agencies regarded this newly created agency with distrust (interview 02), and as the manifestation of the central Government's intention to establish a hierarchy between them (interview 01). This perception was intensified by ANECA's behaviour during these first years, as it largely ignored the rest of the agencies (interview 02) and tried to impose itself as a hierarchically superior agency (interview 2). In fact, during the first year of existence, there was no contact between ANECA and the regional agencies (interview 01).

However, the role of regional agencies was enhanced by ENQA's strategy of recognition of regional and state agencies on equal terms. For European authorities, the promotion of a "competition" framework between agencies was an objective which aimed to strengthen the extension and consolidation of the quality assessment model. But, on the other hand, the extension of the regional agency model in Spain clashed with its political and administrative tradition, based on the centralized regulatory control at the State political level. Therefore, in this first stage, the relationship between ANECA and the regional agencies was marked by the tension involved in determining the competence policy areas and the definition of the hierarchy and the collaboration system between the different regulatory bodies (interview 01). The pretension to establish hierarchy on the part of the central Government clashed with the political autonomy that regions intended to continue maintaining (interview 2).

\subsection{ANECA's development and adaptation in a context of rapid policy change (2004- 2010)}

Since its establishment in 2002, ANECA went through substantial transformations that were influenced by the own construction of the EHEA. According to ANECA's report to the ENQA of 2007, the absence of specification of the approaches to be applied for the evaluation of higher education in the legislative framework determined "the commitment by ANECA's governing bodies to organize its evaluation processes in accordance with Standards and Guidelines for Quality Assurance (ESG) in the European Higher Education Area (EHEA)” (ANECA, 2007: 5). 
In 2006, two years after the victory of the Spanish Socialist Workers' Party (PSOE) that ended eight years of conservative government, Gemma Rauret, former director of the Catalan regional quality agency, was appointed as the new director of the ANECA. She steered the agency in a period characterized by a crucial transformation of the Spanish system of quality assurance: its shift from being voluntary to being compulsory. This strengthened ANECA, since in order to operate, the universities needed the ANECA to produce a favourable report. Thus, in 2007, Royal Decree 1393/2007, 29 October, established a new qualifications system and defined a compulsory system of accreditation for degrees. As a consequence, ANECA launched a series of programs that intended to accredit all degrees in Spain within a period of three years, in parallel with the implementation of a system for the accreditation of university professors.

These programs were not welcomed by everybody. The implementation of a compulsory system in 2007 (particularly regarding the accreditation of programs and professors) encountered significant resistance in universities who maintained the new control formulas clashed with the autonomy principles. ANECA's role in this reform was also criticized. A common complaint during this period was that ANECA demanded too much information, much of which was considered irrelevant and even "absurd" 2 .

In parallel, the ANECA and the regional agencies start working closely during these years. According to one interviewee, the creation of the Spanish Network of Agencies (REACU) in 2006 was crucial for this. In the REACU, ANECA and the regional agencies met several times a year to negotiate the criteria and methodologies of assessment (interview 1). Despite the initial resistance to participate, the Catalan agency AQU also joined this network in 2010 (interview 1).

\subsection{Adjustments and revisions towards the agency consolidation (2011-2018)}

Amid the economic crisis, the Popular Party (the conservative party which won the 2011 elections) started a reform process with the objective of reducing public spending and eliminating redundant administrative structures. The report written in 2013 by the Committee for the Reform of the Public Administrations proposed a series of measures for the re-structuration of the Spanish system of public administration, that included the fusion of public entities to avoid duplication ${ }^{3}$. In line with this, the report suggested the establishment of a unique accreditation body in the area of higher education (CORA, 2013:

\footnotetext{
2 Carlos Berzosa, “Sí a Bolonia, pero no así”, 9 of June 2008, El País Madrid.

3 http://transparencia.gob.es/transparencia/dam/jcr:16c7ed96-bab3-4adb-943e-6c1730dd5785/reforma-AAPP-ingles.pdf
} 
112). Consequently, some regional agencies were afraid that this reform would trigger a process of centralization, that would reduce their area of competence (interview 03).

One year after, Act 15/2014 of 16 September transformed the ANECA into an autonomous body (art. 8) ${ }^{4}$ and augmented its competences, putting the National Committee for the Evaluation of Research Activity (CNEAI)under its coordination, as recommended. The competences of the regional agencies remained, however, untouched, as the director of the ANECA at the time opted for respecting their area of competence (interview 03).

It seems, therefore, that the ANECA, when having the opportunity for centralization, opted for a model based on cooperation with regional agencies. Similarly, insights from the interviews show that the relationship with the other regional agencies were oriented, in this third period, by the mutual recognition and collaboration principle (interview 3). According to an interviewee from the AQU, "now the relation between the ANECA and AQU is of equals, (...) as we are all in the same European registry” (interview 03). It therefore appears that the role of this Registry has contributed to the ease of the territorial conflict. This is potentially due to the consolidation of the collaboration strategy over the hierarchy on the multilevel governance quality assessment system.

\section{Conclusions}

In this paper we present a work in progress examining the case of quality assurance in Spain, disentangling the evolution of an agency, the ANECA, that made its way in a context characterized by deep policy transformations and by multiple actors involved. Our goal has been examining Spain as a case of these substantial policy changes in Europe, to focus on several questions that try to better understand such a large institutional change.

So far, we were able to identify some factors that may explain the evolution of the ANECA, in a multi-level environment, with strong regional actors. On the one hand, we have seen that the ANECA interacted with the regional agencies and was able to overcome an initial inter-agency confrontation, moving to a more innovative and collaborative model of relations. In this regard, it seems that the fact that strong regional agencies were already in place when the ANECA was established, limited its margin of action and force the national agency to move to a model based on extended cooperation and information sharing with the existing agencies. On the other hand, the impact of the European policy framework in a domestic policy environment helped too to facilitate this transition to a more collaborative

\footnotetext{
${ }^{4}$ Royal Decree 1112/2015, of 11 December, approved the Statute of the ANECA, which describes it as "a separate public legal entity, has its own Property and treasury as well as full legal capacity to act and use its power with complete functional independence” (art. 1.2).
} 
interrelation between centre-periphery relationships. For European Institutions, the different agencies registered in the ENQA have the same consideration and action capacity, regardless of whether they are national or regional. This favoured the consolidation of a relational model guided by the principle of mutual recognition and collaboration.

To conclude, it must be noted that more evidence is still needed to adequately assess the evolution of this agency. Other possible explanations such as the impact of personal leadership should also be explored. In order to do that, more interviews are planned to be conducted. Proximately, we hope to add these results to this paper.

\section{References}

ANECA (2007). Self-evaluation report.

Blackmur, D. (2007). The public regulation of higher education qualities: rationale, processes, and outcomes. In Quality assurance in higher education (pp. 15-45). Dordrecht: Springer.

CORA (2013). Reform of the Public Administrations. Madrid: Ministry of Finance and Public Administrations.

Dill, D. D., \& Beerkens, M. (2013). Designing the framework conditions for assuring academic standards: lessons learned about professional, market, and government regulation of academic quality. Higher Education, 65(3), 341-357.

Dobbins, M. \& Knill, C. (2014). Higher Education Governance and Policy Change in Western Europe. Basingstoke: Palgrave Macmillan.

ENQA (2007). Report of the panel of the ENQA coordinated review of ANECA against the Standards and Guidelines for Quality Assurance in the European Higher Education Area. June.

ENQA. (2005). Standards and guidelines for quality assurance in the European higher education area.

Musselin, Christine (2014), "Empowerment of French universities by funding and evaluation agencies”, Research in the Sociology of Organization, 42: 51-76

Olsen, J. P. (2007). The institutional dynamics of the European University. In P. Maassen \& J. P. Olsen (Eds.), University dynamics and European integration (pp. 25-54). Dordrecht: Springer.

Westerheijden, D. F. (2007). States and Europe and quality of higher education. In D. F. Westerheijden, B. Stensaker, \& M. J. Rosa (Eds.), Quality assurance in higher education (pp. 73-95). Dordrecht: Springer. 